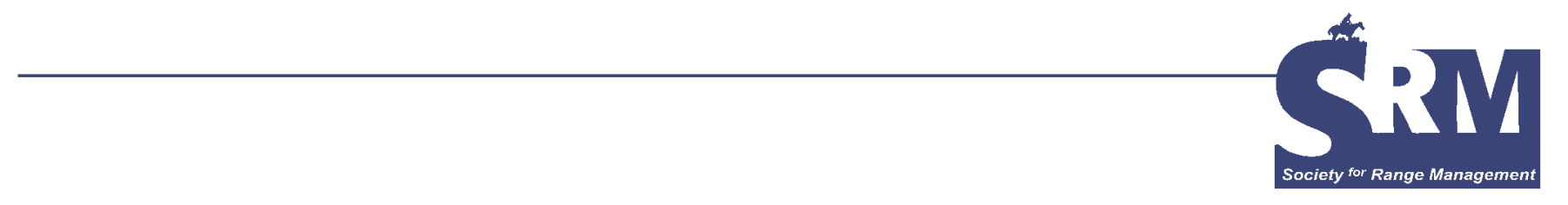

\title{
Twelfth in a Series: Insight From SRM's Charter Members
}

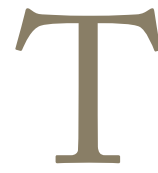

he SRM History Committee has conducted interviews with many of the Society's Charter Members to capture their perspective of events leading to and subsequent to the formation of the American Society of Range Management in 1947-1948. Interviews from several of these individuals will be shared for today's SRM members to enjoy and learn from.

\section{SRM Charter Member - Robert S. Rummell Editor's Note: Bob Rummell sent his written responses to inter- view questions to Bill Hurst in November 2004. They are slight- ly modified to fit this format. Bob can be reached at 5406 Newington Rd, Bethesda, MD 20816-3316.}

In 1944, when I reported for duty as a junior range scientist at the Pacific Northwest (PNW) Forest and Range Experiment Station in Portland, Oregon, I soon learned that professionals in range science and management, as well as many ranchers, wanted to have a society that more nearly represented their interests rather than to continue to be affiliated with societies that focused on other disciplines. This came from G. D. Pickford and Elbert H. (Bert) Reid. Then, in late 1944 or early 1945, Joe Pechanec was transferred to PNW as Station Chief of Range Research. Joe became the spark for our group of range folks, as I am sure he was in his prior assignment at the Sheep Station, Dubois, Idaho, in advancing the idea that range people would be better served were they to be represented by a society that more nearly focused in on the problems, work, and other aspects that were important to us. It was OK to publish in the Journal of Forestry, the Journal of Ecology, or one of the soils journals, but it was felt there would be more opportunity for the range folks to advance, to spread what we believed in and had found out, if we could talk from our own platform. It also would be important if such a society could include ranchers and other users of rangelands.
Important to the prehistory of our Society was a March 1946 Interagency Range Management Conference held in Moscow, Idaho. Vigorous discussions during that meeting were held on the need for a range management organization. Dr Vernon Young, University of Idaho, chaired that portion of the meeting. Attending the meeting were representatives from Economic Research Service (ERS), Forest Service (FS), Grazing Service (GS), Soil Conservation Service (SCS), Idaho Fish and Game, Washington Fish and Game, the old Production and Marketing Service of the US Department of Agriculture (USDA), University of Idaho, Montana State College, Oregon State College, University of Montana, and Washington State College. Bureau of Land Management (BLM) may also have been at this meeting. Four later-elected presidents of SRM attended the 1946 conference-Joe Pechanec, Mel Morris, Dr Young, and Dr Harold Heady.

Because I was probably the junior person there, Joe Pechanec nominated me to be Secretary Pro Tem. My notes, turned over to Dr Young, were, fortunately for the good of the Society's prehistory, thoroughly reviewed and completely revised by him. As the Society came into being, as I recall, Terry White, SCS state range employee of Portland, Oregon, became the first Executive Secretary. He was succeeded by John Clouston, a Forest Service range manager, also from Portland.

I did not attend the Salt Lake City, Utah, initial annual meeting. Joe Pechanec had sent me off to attend a 3-month statistical training session in Washington, DC, that ended just about the time the first ASRM meeting was adjourning. My first meeting was either in Boise, Idaho, or the one in Albuquerque, New Mexico. I don't recall which came first. Other meetings in Great Falls, Montana ( $45^{\circ} \mathrm{F}$ below zero); Las Vegas, Nevada (reindeer meat served at the banquet); 
and other locations, all have good memories. Some of the regional and local meetings were outstanding. And, some of the early projects were also outstanding and advanced the goals and causes of good range management.

One of the projects that the PNW Section took on around 1950 was to further interest and inform young people about range. Youth range camps were organized. One of these was held on the Colville National Forest. My role was to teach the attendees how to identify different grasses. Back then, we didn't have all of the technology that today's educators have. My teaching technique was to use a flannel graph, where the individual parts of the grass plant could be attached or removed - the lemma, the palea, glumes, etc. (Lucky I can still remember those parts!)

In the period 1953-1960, I was assigned to a range research program on the flatwoods in south Florida. I do not recall that we held many formal SRM Section meetings during that period. Society members did get together as part of our work. One such meeting was held in Tifton, Georgia, the location of cooperative range work being done between personnel of the SE Forest Experiment Station and a unit of the University of Georgia. Society members Lowell Halls and Ralph Hughes did much of the FS range research out of Tifton during that period. In the early 1960s, the National Capital Section was quite active, although with a small membership. One of the Section's goals was to have the Society move its headquarters to the DC area. That effort, of course, did not succeed. In 1965, Clint Wasser appointed me to cochair the program committee for the 1966 annual meeting. Lowell Halls was to be the other cochair. The meeting was held in New Orleans, Louisiana.

Although the following events were not Society-sponsored, they bear recalling because many members of the Society participated and, I hope, profited from that participation.

During the course of coordinating some of our FS rangeplanning activities with Colorado State University (CSU), Dr Don Jameson, a member of Dr C. Wayne Cook's range staff, told me about some of their range ecosystem-focused research. CSU was interested in furthering and extending that work. FS headquarters personnel became interested and OK'd going ahead with CSU to set up an initial short course or workshop in ecosystem management planning. That short course was held in Estes Park, Colorado, in early spring of 1969 or 1970. Attending were about 30 FS managers, including FS Associate Chief Rex Resler. (I regret having no record of the meeting-archival records should reveal the details of arranging and reports on this workshop.)

Following that initial short course, we sponsored a series of ecosystem planning workshops during a period of several years beginning in 1970 in further cooperation with CSU. Ultimately, as many as 800 FS managers and specialists attended, including representatives from other federal agencies. CSU initially provided the staff and the curricula. (Other universities later picked up on this concept of training federal employees in ecosystem management planning.)
Another FS activity that involved many SRM members was initiated in about 1969. This 50-state effort became known as the Forest Range Environmental Study. All lands in the 48 states were included, irrespective of ownership. Personnel from federal, state, and other agencies participated. Reports on the studies' findings were published in 1972. A 1977 publication reporting on range-type data, assembled during the 1969-1972 study, included a map that showed the major forest and range ecosystems of the United States.

How did I become interested in range? Before I became interested in range, I thought I would like to be a fire lookout. This ambition came into being during a 17-day canoe trip in 1936 as a Boy Scout when in northern Minnesota. We crawled up the ladder of a remote fire tower and looked out over miles and miles of northern pine forests and the myriad lakes of that then-wild country. That ambition soon vanished.

In 1937, I enrolled in forestry at Iowa State College (now ISU), where my interest became focused on range management during a 1939 ISU junior-year summer session held on the Malheur National Forest in eastern Oregon. During that summer, we visited Murderer's Creek, where an overpopulation of mule deer had decimated the bitterbrush, Mountain mahogany, and other browse. Other exposure to the problems and needs of range during that summer, including discussions with some local ranchers, led me to decide to major in range management during the rest of my time at Ames, Iowa. Guiding that interest was professor Odell Julander, a transplanted Utahan, who later became a professor at the University of Arkansas.

When the Society was being formed, it was out of the question to not want to become a member of the society that was to represent my life's chosen profession. Although I had already become a member of the Society of American Foresters (SAF) and knew the SAF had a unit that covered range management, I recognized, as did the principal founders of SRM, that to be attached to SAF was to be an appendage to a larger animal. We needed to be our own animal.

My first Section was PNW. Other Sections in which I was a member were the Southern Section, and the National Capital Section. Planning for Sections must have been in the thought from the beginning. According to my records, the PNW Section had its third annual meeting in Baker, Oregon, November 1 and 2, 1952. I presented a paper on cheatgrass at that meeting. I don't have records of the first and second PNW section meetings, so I don't know for sure when they were held. I do recall, however, attending another PNW section meeting, I believe in Yakima, Washington, before 1953, probably in 1951. I recall giving a paper at that meeting, also.

I'm not sure that I can project back some 55 or more years and recall what I expected from ASRM. I was just a young professional interested in getting ahead in my chosen profession and probably looked to the Society as one of those things a person must belong to if you wanted to go with the flow, meet the right people, and find out what others were 
doing and their interests. Making a contribution to the health of the range, I hope, was part of my hopes for the young Society. The Society has been successful in meeting the initial hopes and goals of the heavyweight founders, such as Joe Pechanec, our first President; the Harold Headys, C. Wayne Cooks, and Lincoln Ellisons of academia; and, I would hope, the many progressive ranchers who contributed their ranching experiences and leadership to the Society.

I spent my entire career with the FS in research. My first assignment as a USDA Forest Service range researcher was in the Pacific Northwest of the United States. In the mid1940s, we were concerned about finding out how we could improve summer ranges through introduction of forage grasses. With the help of SCS agronomists Dr A. L. Hafenrichter and John Schwendiman, who provided seeds they felt might be useful to us, we established experimental plantings on national forest ranges from the Lakeview area of southern Oregon to north-central Washington. From that work, we were able to publish a number of articles and USDA reports on how to successfully seed those summer ranges. Learning more about the effects of grazing and logging on range in the ponderosa pine forests was part of my work during this period. I also became interested in the effects of fire and its exclusion on those forests.

US Bureau of Indian Affairs worker Harold Weaver had shown by the early 1940s on the Colville Indian Reservation that exclusion of fire from ponderosa pine forests of northern Washington had led to the establishment of "dog-hair" stands of stagnated pine seedlings - in some instances, one 30- to 40-year-old pine seedling per square foot.

Weaver was a pioneer in apprising folks of some of the bad effects of a policy of controlling all fires in the ponderosa pine forest type. Using his published work as a lead, and after our own research, I wrote several papers and reports that related to the ecology and effects of fire and grazing on ponderosa pine forest ranges.

During the years 1953 to late 1959, I was assigned to southern Florida to undertake a research program in grazing management on pine ranges. That assignment was not highly productive. I soon realized that grazing of cattle on the slash-pine flatwood ranges of southern Florida could only be successful if ranchers took advantage of increased plant protein from grass regrowth following burning, supplementally fed their cattle, or used improved pastures-all of these in some combination. The wiregrass range, by itself, could not provide enough nutrition for cattle of high breeding to have high calf crops and birth and weaning weights. That already was common knowledge among progressive ranchers and researchers, such as Elver Hodges, SRM member and scientist for the State of Florida Experimental Station at Ona, Florida.

From 1960 until I retired in late 1980, I was assigned to the Washington office of the Forest Service Division of Range Management. My assignments there were many and varied, and most were in line with the goals of SRM. One assignment was to work with FS regional range personnel on development and coordination of range-analysis programs. During this period, we undertook several range-centered studies of national scope. One of those was titled "A Trial Program for Public Land Range Appraisal."

Congress had directed the FS and the BLM, in 1962, to do studies that might lead to development of improved range-management programs on the public rangelands administered by both agencies. Cyril Jensen, BLM (ASRM member), and I, with the help of other range professionals, put together plans for studies to be made during the trial program. The studies concluded that an appraisal of the 242 million acres of lands administered by the 2 federal agencies upon which livestock then grazed would be valuable in bringing about the full productive potential of these lands. That study proposed methods for a public land range appraisal. (See Doc. No 119; 87th Congress, 2nd session).

Somewhat later, I was given the assignment to chair an FS task force that was to look for a new planning methodology for resource allocation. That assignment, focusing on range, gathered information about all the Nation's range and developed a technology for its evaluation. Although focusing on range, the studies put range within the total natural-functioning ecosystem but with consideration of other resource and resource uses beyond grazing animal use.

Information from all range and forest ecosystems in the 48 contiguous states was assembled by teams of people representing the disciplines of forestry, range, ecology, watershed, hydrology, soils, economics, recreation, landscape architecture, and computer science. Furnishing data and advice were the BLM, National Park Service, Fish and Wildlife Service, Bureau of Indian Affairs, ERS, SCS, and the Agricultural Stabilization and Conservation Service. Results of this nationwide effort were published in several reports in 1972, with the principal report entitled "The Nation's Range Resources-a Forest-Range Environmental Study." Many of the more than 100 participants in this study were SRM members.

Some later assignments that were related to, and of significance to, the goals of SRM were: Leader, USDA Interagency Task Force on Red Meat Production from Ranges of the USA, 1972-1974; Coordinator, USDA Interagency Work Group on Range Production, 1974-1976; Principal Staff, USDA Interagency Work Group on Range Policies and Programs, 1978-1979; and Executive Secretary, USDA Departmental Committee on Range, 1978-1980. In all of these latter assignments, the Society for Range Management was represented by agency staff assigned to the various task and work groups and the Departmental Committee.

I took part in both Section and National Society activities in the 1950s and 1960s. I was able to participate in many Society meetings with the support of the Forest Service. I have not been active in the Society in recent years, and I respect what SRM has done. 
As one of the first professional groups to show its concern for the whole universe of the environment, not just 1 commodity, SRM deserves much credit. Many members of SRM have been leaders in promoting wise use of our nation's wildland resources. The Society has been a significant influence in sponsoring good range management on ranges around the world.

The Society has been very good for the large portion of our nation that traditionally has been productive of forage and habitat for grazing animals. From its beginnings, Society members looked broadly at the forest and range environment, recognizing that to wisely use the range was to benefit not only livestock production but also other use demands. I admit, when I began to work in the field of range management, I did not recognize the value of standing snags for bird life. Nor was I as concerned as I later became about trampling and other disturbances by cattle to a stream.

What would I tell young people who wish to make a contribution to the rangeland resource? I would tell them, if they can and intend to get a higher education, to get as broad an exposure as possible to the elements that make up the total environment. Go where a course of study makes you look not only at soils, geology, range, ecology, and social interactions but also gives you the basis for integrating all of those and other elements into a working model that you can use to benefit the rangeland resource portion of the total environment. If you can't do that via a "range" curriculum, then go where you can get that kind of educational experience. The range profession was good to me. It enabled me to have a satisfying career of about 40 years. The American Society of Range Management, later the Society for Range Management, helped me contribute some things of value to the profession and to society, I hope.

Tom Bedell is a member and former chairman of the SRM History Committee and a member of the Pacific Northwest Section living in Philomath, Oregon, tbedell@peak.org.

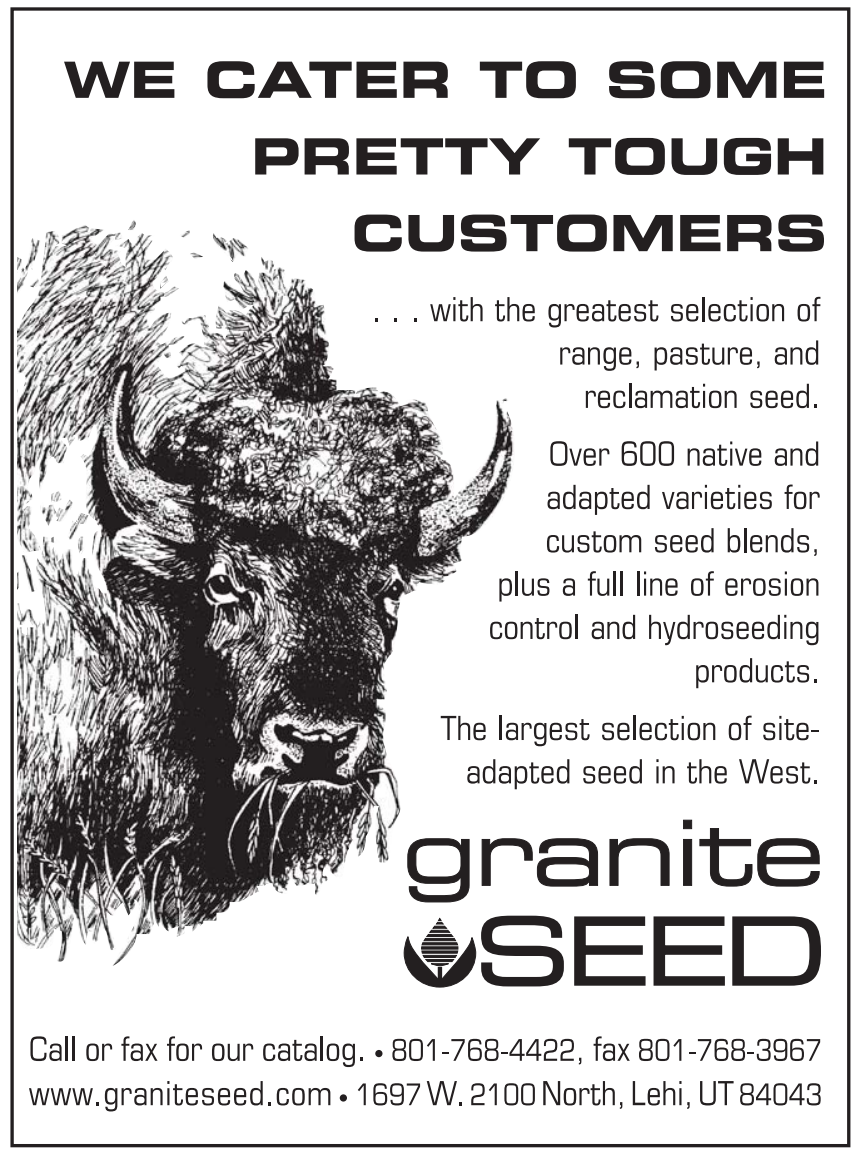

